\begin{tabular}{|l|l|l||}
\hline \multicolumn{2}{|c|}{ PublisherInfo } \\
\hline \hline PublisherName & $:$ & BioMed Central \\
\hline \hline PublisherLocation & $:$ & London \\
\hline \hline PublisherImprintName & $:$ & BioMed Central \\
\hline \hline
\end{tabular}

\title{
MicroRNA microarray disarray?
}

\begin{tabular}{|l|l|l||}
\hline \multicolumn{2}{|c|}{ ArticleInfo } \\
\hline \hline ArticleID & $:$ & 4988 \\
\hline \hline ArticleDOI & $:$ & $10.1186 /$ gb-spotlight-20040802-02 \\
\hline \hline ArticleCitationID & $:$ & spotlight-20040502-02 \\
\hline \hline ArticleSequenceNumber & $:$ & 51 \\
\hline \hline ArticleCategory & $:$ & Research news \\
\hline \hline ArticleFirstPage & $:$ & 1 \\
\hline \hline ArticleLastPage & $:$ & 1 \\
\hline \hline & & RegistrationDate : 2004-8-2 \\
\hline ArticleHistory & $:$ & OnlineDate \\
\hline \hline ArticleCopyright & $:$ & BioMed Central Ltd2004-8-2 \\
\hline \hline ArticleGrants & $:$ & \\
\hline \hline ArticleContext & $:$ & 130595511 \\
\hline \hline
\end{tabular}


A paper in Proceedings of the National Academy of Sciences USA this week reporting that a signature of microRNA (miRNA) gene expression correlates with diagnosis and prognosis of B-cell chronic lymphocytic leukemias (CLLs) has drawn skepticism from others in the field (Proc Natl Acad Sci USA 2004, DOI:10.1073/pnas.0404432101).

Carlo M. Croce's group at the Kimmel Cancer Center, Thomas Jefferson University, Philadelphia, report the use of a miRNA microarray, recently described, to identify significant differences in miRNome expression between CLL samples and normal CD5+ B cells. "The results were extremely exciting because they showed a signature of miRNA gene expression that correlates with diagnosis and prognosis of CLL," Croce told us.

Two signatures were found. One correlated with mutations in the variable region of the immunoglobulin gene - a good prognostic indicator, according to Croce. The other correlated with the deletion of chr13q14 - a region containing two small miRNA genes that are downregulated in about $60 \%$ of CLL.

"There was only one common denominator between these two signatures, and that was the downregulation of miR-16, which is in fact the miR that we found deleted in CLL," Croce said. That suggested that miRNA gene expressions could be used as diagnostic and prognostic indicators, he said. "That could be tremendously useful in cancer treatment, in cancer prevention, and in cancer diagnosis."

"The fact that you can distinguish potentially between benign and malignant tumors certainly would suggest miRNAs would be an appropriate target for further investigation," said Thomas J. Fahey, associate professor at Weill Cornell Medical College and New York-Presbyterian Hospital.

A number of other researchers in the field refused to comment on the paper.

However, one researcher said that although he believed nothing was technically wrong with the experiments carried out in the paper, he did not agree with the interpretation of the data. "The analysis is extremely basic," Mike Hubank, who heads a research group in the Molecular Haematology and Cancer Biology Unit at London's Institute of Child Health, told us. "They effectively just follow the GeneSpring protocol for doing basic analysis. In principle, there's nothing wrong with that, so long as you recognize that limited analysis gives you limited scope for making sense of your data."

But George Calin, the first author of the paper, said that the team had done everything that was done with "normal EST" chips. "We are using GeneSpring, and we are using the same basic steps as for normal chips," Calin told us, saying that there was a "standard way" of dealing with the data.

According to Hubank, who was not involved in the study, quality control and filtering measures are inadequately described in the paper, so genes may have been expressed at a level below that which is detectable by the system. "You've got to be careful about what data you feed it [the hierarchical clustering software], and you've got to be careful about the interpretations you make from it," Hubank said. 
Calin, also of the Kimmel Center, said that all the conditions and controls were the same as those described in their Proceedings of the National Academy of Sciences USA paper published online before print on June 21.

Referring to the miRNA microarray, Hubank said, "There is this curious thing where they've got mouse and Arabidopsis RNAs on there. It's not clear whether they just selected the human subset of genes for analysis, so this may be a problem, too." Calin said that the nonhuman RNAs were present as negative controls.

Hubank noted that none of the microarray data described in this or the first paper could be accessed from the microarray database at ArrayExpress. "[The authors] have provided sample numbers in the paper rather than experiment identifiers, and you can't search on sample numbers," he said. "I also can't find it by searching on lab or group leader's name. ArrayExpress' Alvis Brazma said that he could not find the data either and that the authors may not have completed submission yet. Calin said he was not sure if they had or not.

There were not enough normal controls, Hubank said, saying also that the authors were overinterpreting the data. "They're comparing the CLLs with the normals and then trying to differentiate the CLLs into different subtypes of CLLs - and you just can't do that with the type of analysis they're performing," he said.

"They've tried to suggest there's some sort of prognostic value in these things - it's just not the case," Hubank said. A proper mathematical approach - such as generating a classifier based either on probability or on a proper model-based prediction using supervised clustering - would be needed for such an assertion, he said, and there was insufficient data for the first possibility. "They have just taken genes and said these things are expressed more in here than they are in there, therefore this is a good classifier," he said. "You can't do that."

\section{References}

1. Proceedings of the National Academy of Sciences USA, [http://www.pnas.org]

2. Carlo M. Croce, [http://cll.ucsd.edu/biographies/croce.htm]

3. An oligonucleotide microchip for genome-wide microRNA profiling in human and mouse tissues

4. Thomas J. Fahey, [http://www.cornellphysicians.com/tfahey/researchprofile.html] 
5. Mike Hubank, [http://www.ich.ucl.ac.uk/ich/html/academicunits/mol_haem/research_dna.html]

6. GeneSpring, [http://www.silicongenetics.com/cgi/SiG.cgi/Products/GeneSpring/index.smf]

7. ArrayExpress, [http://www.ebi.ac.uk/arrayexpress/]

8. Alvis Brazma, [http://www.ebi.ac.uk/Information/Staff/person_maint.php?person_id=181] 